\title{
COMPARISON BETWEEN PAPER-BASED AND WEB-BASED TEST IN THE CLINICAL SKILLS LABORATORY OF UNDERGRADUATE STUDENTS
}

\author{
Doni Widyandana ${ }^{*}$ \\ ${ }^{1}$ Faculty of Medicine, Public Health and Nursing Universitas Gadjah Mada, Yogyakarta - INDONESIA
}

\begin{abstract}
Background: E-Learning or web-based technology can be used to train undergraduate medical students' clinical reasoning skills. Currently, many learning methods are being developed using web-based environment to replace paper-based because they are more efficient in terms of paper usage and are flexible for a student in accessing materials. This study aims to explore student's working durationaccess time and scores upon the usage of webbased test, to compare students' scores to paper-based test scores, to explore the advantages anddisadvantages, and suggestions to improve the web-based learning method.
\end{abstract}

Method: This study randomly enlisted 60 medical students of Universitas Gadjah Mada, Yogyakarta, Indonesia and divided them into web-based $(n=30)$ and paper-based test $(n=30)$ groups. Students answered 15 disaster management questions and completed a questionnaire. The scores and times needed to answer the questions were compared using the Mann-Whitney and Independent Sample tests.

Results: The duration to answer in the web-based group was shorter than in paper-based group $(p=0.001)$, but the average scores difference was not significant $(p=0.169)$. In the web-based group, similar numbers of students accessed the website during and after working hours. Survey questionnaire results showed that most students realized the advantages of this program and gave appropriate suggestions.

Conclusion: Practicing clinical reasoning skills using web-based learning method is more time-efficient compared to the paper-based test. Its high-accessibility improves the learning interest and motivation of the student, with an equal outcome to the paper-based test.

Keywords: Web-based learning, time efficiency, undergraduate, clinical reasoning

\begin{abstract}
ABSTRAK
Latar belakang: Teknologi media ajar berbasis internet dapat digunakan untuk melatih kemampuan penalaran klinis mahasiswa kedokteran. Saat ini, banyak pengembangan metode pembelajaran yang menggunakan media situs untuk menggantikan pembelajaran berbasis kertas karena lebih efisien dalam hal penggunaan kertas dan fleksibilitas waktu mahasiswa dalam mengakses pembelajaran. Penelitian ini bertujuan untuk mengeksplorasi durasi pengerjaanwaktu akses dan nilai siswa saat mengakses situs, untuk membandingkan nilai tes-berbasis-situs siswa dengan nilai tes berbasis kertas, dan untuk mengeksplorasi kelebihan, kekurangan, dan saran untuk memperbaiki metode pembelajaran berbasis web.

Metode: Penelitian ini melibatkan 60 mahasiswa kedokteran Universitas Gadjah Mada, Yogyakarta, Indonesia dan membagi mereka menjadi kelompok web-based $(\mathrm{n}=30)$ dan kelompok uji berbasis kertas $(\mathrm{n}=30)$. Siswa menjawab 15 pertanyaan manajemen bencana dan menyelesaikan kuesioner. Nilai dan waktu yang dibutuhkan untuk menjawab pertanyaan dibandingkan dengan uji Mann-Whitney Test and Independent Sample.
\end{abstract}

*corresponding author, contact: widyandana@ugm.ac.id 
Hasil: Durasi untuk menjawab dalam kelompok berbasis situs lebih pendek daripada kelompok berbasis kertas $(p=0,001)$, namun perbedaan nilai rata-rata tidak signifikan $(p=0,113)$. Dalam kelompok webbased, jumlah siswa yang sama mengakses situs web selama dan setelah jam kerja. Hasil kuesioner survei menunjukkan bahwa sebagian besar siswa menyadari kelebihan program ini dan memberi saran.

Kesimpulan: Mempraktikkan kemampuan penalaran klinis dengan menggunakan teknologi situs lebih hemat waktu dibandingkan dengan tes berbasis kertas. Mahasiswa dapat mengakses kapan saja, menyenangkan, serta meningkatkan motivasi belajar. Hasil nilai tesnya juga tidak jauh berbeda dengan tes berbasis kertas.

Kata kunci: Web-based learning, waktu efisien, sarjana, penalaran klinis

\section{INTRODUCTION}

In recent years, the clinical reasoning skills of Indonesian's medical personnel are still in question. The study of 132 students of the Faculty of Medicine, University of Sriwijaya identified four out of ten medical students had poor clinical reasoning skills. ${ }^{1}$ The condition was considered dangerous because poor clinical reasoning skills can lead to the failure of patient rescue attempts. ${ }^{2}$

Seeing the problem above, clinical reasoning is a mandatory subject for undergradute medical students in the clinical skills laboratory. Medical skill education in the skills laboratory has been proven to give a positive effect on the clinical setting. ${ }^{3}$

During this time, clinical reasoning exercises are mostly done through theoretical learning and provide practice problems using paper-based media. Nevertheless, the paper-based media used for clinical reasoning exercises has some disadvantages, such as it uses a lot of paper for printing, which, after being used, are mostly discarded. Besides, access times are limited to the working hours and require human resources to run the process. Due to these problems, the idea was formed to utilize webbased technology in skills education in the skills laboratory. Web-based learning, is one solution that can be applied as it can provide learning materials anytime by utilizing electronic media. ${ }^{4,14}$ The flexibility of place and time helps students to create their learning schedule without limitation from sources and learning media. ${ }^{5}$
This study was conducted to determine the effectiveness of web-based learning in terms of working duration, test scores, access time, and students' suggestion for the web-based system. Collected data and information can be used for the development of web-based learning to support students' learning activities better.

\section{METHODS}

This research used descriptive research design for 60 third-year students of the Faculty of Medicine, Universitas Gadjah Mada, Yogyakarta, Indonesia from eight tutorial groups who were randomly selected. The research subjects were asked to do the test within 21 days. The test material involved clinical reasoning problems, which consisted of six types of exercises related to disaster management incidents such as fire, flood, earthquake, volcanic eruption, landslides, and storms. After this step, the students completed a questionnaire containing questions about the benefits, disadvantages, and suggestions about web-based learning usage.

Subjects were divided into two groups, web-based group $(n=30)$ and paper-based group $(n=30)$. The web-based group worked on the test and the questionnaire by accessing the website of Gadjah Mada Medical E-Learning (Gamel) which can be accessed freely by the student anytime in 24 hours and in any place which has an internet connection. The subjects of the paper-based group were administered the test and the questionnaire at the FK UGM Skills Laboratory Office during working 
hours accompanied by the laboratory administrator. The test consisted of 15 questions with 15 minutes working time limit. The Gamel system did this time restriction automatically, and the score would automatically appear when the time ran out. Meanwhile, the paper-based group was asked to record the starting time and the finishing time of the test. Each test obtained by the subjects, both web-based and paper-based, was given randomly, automatically in the web-based group and by officers in the paper-based group, to avoid cheating.

Web-based learning effectiveness was evaluated based on test duration, test scores, and access time. Access time will be determined from the web-based group. Web-based group subjects were divided into two groups, during working hours (8:00 to $12: 00$ and $13: 00$ to $16: 00$ in five working days) ( $n$ $=20$ ) and non-working hours (before 08:00, 12:00 to $13: 00$, and after 16:00 in five working days) ( $n$ $=20$ ). Saturdays and Sundays were counted as non-working hours for 24 hours. Test scores were compared using the Mann-Whitney Test. Test duration was evaluated using the Independent Sample t-Test. The questionnaire results were analyzed by deductive methods by two coders who are skills laboratory teachers. The object of this research was web-based test efficacy, and the evaluation has become a regular program in skills lab FM UGM, so it does not require ethical clearance.

\section{RESULTS AND DISCUSSION}

The study involved 60 students randomly selected as research subjects, with a total of 30 subjects in each group. The gender distribution of each group as followed respectivelypaper-based group: men $=6$ $(25 \%)$, women $=24(75 \%)$; Web-basedgroup: men $=6(25 \%)$, women $=24(75 \%)$.

The average test duration in the web-based group was significantly faster than the paper-based group $(p=0.001)$ (Table 1). Test duration in the webbased group was recorded automatically by Gamel with 15 minutes working time limitation. The test duration data in the paper-based group were poorly controlled due to the limited human resources of Skills Laboratory Office, so that the test working time was unsupervised and uncontrollable. A total of 15 subjects from the paper-based group did not fill the start and finish of required expertise. However, the unlimited time of paper-based test allowed us to conclude that participants tend to work on the test more slowly when this method is used.

The test score results between the two groups did not differ significantly $(p=0.169)$. Both groups got poor test scores (see Table 1). Results showed that the clinical reasoning skills of both groups were low. Additionally, there was no significant difference in test scores and test duration between the working hours group and non- working hours group ( $p$ score $=0.687 ; p$ duration $=0.537)($ see Table 2$)$.

Table 1. Test duration and score result

\begin{tabular}{lccccc}
\multicolumn{1}{c}{ Group } & $\mathbf{N}$ & Duration $(\mathrm{mean})$ & Sig. $(\boldsymbol{p}$ value) & Score (mean) & Sig. $(\boldsymbol{p}$ value) \\
Web-based & 30 & 9 minute 12 second & 0,001 & 53.1 & 0.169 \\
Paper-based & 30 & 19 minute 24 second & & 50.0 & \\
\hline
\end{tabular}

Table 2. Test working time

\begin{tabular}{llccccc}
\multicolumn{1}{c}{ Time } & $\mathbf{N}$ & $\%$ & Score (mean) & Sig. $(\boldsymbol{p}$ value) & Duration (mean) & Sig. $(\boldsymbol{p}$ value) \\
Working hours & 15 & 50 & 54.96 & 0.687 & 9 minute & 0.537 \\
Non-working hours & 15 & 50 & 51.4 & & 9 minute 30 second & \\
\hline
\end{tabular}

Questionnaire results showed that 29 subjects from the paper-based group and 21 subjects from the web- based group considered the given clinical reasoning exercise was helpful (see Table 3). 
Table 3. Questionnaire Answers

\begin{tabular}{llrrr}
\multicolumn{1}{c}{ Question } & \multicolumn{1}{c}{ Answer } & $\begin{array}{c}\text { Group } \\
\text { Web-based } \\
\text { Paper-based } \\
\text { (N) }\end{array}$ & $\begin{array}{c}\text { Total } \\
(\mathbf{N})\end{array}$ \\
\hline Is this clinical reasoning exercise & Yes & 21 & 29 & 50 \\
question advantageous? & No & 2 & 1 & 3 \\
Proper time for clinical reasoning & Spare time & 8 & 3 & 11 \\
exercise questions assignment & After lecture & 9 & 23 & 32 \\
Assignment media & Paper based & 5 & 10 & 15 \\
& Web based & 14 & 12 & 26 \\
Assignment schedule & In campus on working hours & 7 & 19 & 26 \\
& Outside campus area on non- & 12 & 10 & 22 \\
Assignment disadvantage & working hours & & & \\
Suggestion for Gamel & None & 11 & 5 & 16 \\
& Yes & 5 & 13 & 18 \\
& Already well & 6 & 2 & 8 \\
& Needs improvements & 6 & 19 & 27 \\
\hline
\end{tabular}

Subjects identified the benefits which include: helps to train clinical reasoning, emergency skills, and self-evaluation. Subjects define this test as the process of new knowledge acquirement and the evaluation of previous knowledge. Subjects were also motivated to search for more knowledge and to get the real emergency depiction.

"I know that there are still many things that I have not seen, (so) I was motivated to learn more." (B29)

The subject stated that clinical reasoning exercises should be provided at the right time after the related materials are presented, so that the subjects can do the test well. The test should also be given when the students are free from work.

"(Problem should be given) after we finished studying the material. After that, it (the test) can be used to deepen the learning of the materials." (A30)

Most of the subjects, both groups of paper-based and web-based, preferred work on the test through online media or web-based access on campus (53\%) during working hours $(54.1 \%)$ rather than through paper-based medium outside the campus on non- working hours. A total of 13 subjects from the paper-based group were less satisfied with the paperbased system because of the impractical system and inefficient time.

"I had to spend a lot of time to work on the test." (B29)

Some suggestions regarding the use of Gamel in learning activities in the Skills Laboratory of Faculty of Medicine, Universitas Gadjah Mada were expressed by subjects. Gamel is considered to be appropriate learning media but needs some improvement. The improvement is in terms of access, display, updated information system, and learning content.

"It should be more interactive and always be updated using a good reference so that students are sure and doubtless about the content of the material in there (Gamel)." (B3)

Based on the results, the test duration in web-based and paper-based groups was different significantly ( $p$ $=0.001)$. However, the test score and the working time of web-based groups during working hours and non-working hours did not differ significantly ( $p$ score $=0.687 ; p$ time $=0.537$ ). 
The test duration of the web-based group is shorter than that of the paper-based group. The system would automatically close the window and gave the test score afterward. The 15 minutes time limitation made subjects do the test in a hurry, but that system gave more efficient results because it did not require the help of officers to supervise the test. Additionally, the time recording system by the webbased system is also more accurate. Subjects from the paper-based group did their time recording based on the time piece they had, such as watches, clocks, or a different clock on a mobile phone, which could affect the accuracy of time. In addition, due to weak supervision, the subjects tended to take more time to do their test. McKimm et al..$^{5}$ mentioned that web-based instruction systems allowed students to get constructive, timely, and relevant feedback to their progress. Web-based learning can also save time, as evidenced by the shorter duration of the web-based group compared to the paper-based group in this study.

Research conducted by Brown and Saks ${ }^{7}$ stated that instructional allocated time is significantly associated with the results that students obtained in math exams. Results of that study differ from this study, even though the duration of the test was significantly different, but the test scores obtained by students of the web-based and paper-based groups did not differ significantly. Post-registration comparative study on nurses conducted by Duffy et al. ${ }^{8}$ concluded that the students got significantly higher grades in distance learning compared to classroom learning. The results obtained in that study may be different because in this study the students were not given any preparation of materials specifically for the test of clinical reasoning so that students worked with only their prior knowledge.

There were variations of the test scores in the webbased group. The varied results show the variety of clinical reasoning skills level of the students. The paper-based group's test scores tended to be similar to extreme values of test scores where similar test scores (high and low) could be their real test score or the result of cheating. This concern concluded from informal interviews with subjects. The opportunity to commit fraud in the form of cheating was more likely to be done on paper-based groups. The fraud opportunity happened because the test process had no supervision and unlimited time so that students could discuss the answers with other students.

Meanwhile, the subject in the web-based group got 15 minute time limitation when the system would automatically close the test window so that the possibility of cheating was low. Tests using web-based system could also be done at home so that the students could have worked on their own. The possibility of cheating in the web-based group can be done by searching the answers through the Internet, but the limitation of time decreased the chance of that action. One of the paper-based group's subjects stated on their questionnaire that this test's weakness of the high opportunity of discussing the test together with other students made the test less effective. That statement explains that the work with paper-based media is more fraud susceptible.

Limitation in this study is no detailed data on the rationalization of time taken for the paper-based group longer than 15 minutes. For future projection, advanced researches which can support that webbased learning is better than paper based- learning are needed because in this study the difference in the frequency of opinions from students and test results is not significantly different. However, this research can be used as the basis of research that web-based method for learning and assessment provides more benefits in terms of student accessibility and time efficiency $^{11,13}$. In India, a web-based learning session has been implemented in several medical schools and have received positive outcome from the students in the effectiveness of competency-based medical education ${ }^{10}$. This method has also been implemented in Qatar ${ }^{12}$. In a more distant future practice, it is expected that web-based learning will not only be applied in medical schools, but it can also be used as a skill development method for physicians in rural area?

\section{CONCLUSION}

Web-based method was shown to be more timeefficient than paper-based approaches, while, the test scores did not differ significantly between the two groups. This study still demonstrated the 
potential of web-based learniing media, which can be successfully used for undergraduate clinical reasoning education in the skills lab.

\section{REFERENCES}

1. Irfannuddin I. Knowledge and critical thinking skills increase clinical reasoning ability in urogenital disorders: a Universitas Sriwijaya Medical Faculty experience. Medical Journal of Indonesia. 2009 Jan 1;18(1):53.

2. Aiken LH, Clarke SP, Cheung RB, Sloane DM, Silber JH. Educational levels of hospital nurses and surgical patient mortality. Jama. 2003 Sep 24;290(12):1617-23.

3. Widyandana D, Majoor G, Scherpbier A. Transfer of medical students' clinical skills learned in a clinical laboratory to the care of real patients in the clinical setting: the challenges and suggestions of students in a developing country. Education for Health. 2010 Nov 1;23(3):339.

4. Trelease RB. From chalkboard, slides, and paper to e-learning: How computing technologies have transformed anatomical sciences education. Anatomical sciences education. 2016 Nov;9(6):583 602.

5. Sharaf F, Alnohair S. Comparison of medical students' learning approaches between electronic and hard copy team-based learning. International journal of health sciences. 2017 Jan;11(1):1.

6. Zhang D, Zhao JL, Zhou L, Nunamaker Jr JF. Can e-learning replace classroom learning?. Communications of the ACM. 2004 May 1;47(5): 75-9.
7. Brown BW, Saks DH. Measuring the effects of instructional time on student learning: Evidence from the beginning teacher evaluation study. American Journal of Education. 1986 Aug 1;94(4):480-500.

8. Duffy T, Gilbert I, Kennedy D, Kwong PW. Comparing distance education and conventional education: observations from a comparative study of post- registration nurses. ALT-J. 2002 Jan 1;10(1):70-82.

9. Benjamin J, Groner J, Walton J, Noritz G, Gascon GM, Mahan JD. Learning in a web-based world: an innovative approach to teach physical examination skills in patients with neurodisability. Academic pediatrics. 2018 Aug 1;18(6):714-6.

10. Telang A, Rathod S, Supe A, Nebhinani N, Mathai S. Faculty views on competency-Based medical education during mentoring and learning web sessions: An observational study. Journal of Education Technology in Health Sciences. 2017 Apr 29;4(1):9-13.

11. Kitching F, Winbolt M, MacPhail A, Ibrahim JE. Web-based social media for professional medical education: Perspectives of senior stakeholders in the nursing home sector. Nurse education today. 2015 Dec 1;35(12):1192-8.

12. Weber A. Web-based learning in Qatar and the GCC states. Available at SSRN 2825912. 2016 Aug 18.

13. Vogelsang M, Rockenbauch K, Wrigge $\mathrm{H}$, Heinke W, Hempel G. Medical Education for "Generation Z": Everything online?!-An analysis of Internetbased media use by teachers in medicine. GMS journal for medical education. 2018;35(2). 